\title{
The Effect Of Brand Associations: A Field Study On Turkish Consumers
}

Elif Akagün Ergin, (E-mail: eakagun@cankaya.edu.tr), Çankaya University, Turkey Handan Özdemir, (E-mail: h_ozdemir@cankaya.edu.tr), Çankaya University, Turkey Bülent Özsaçmacı, (E-mail: bozsacmaci@cankaya.edu.tr),Çankaya University, Turkey

\begin{abstract}
Over the last decades, companies have significantly increased their investments in the creation and development of brands. The brand creates value for both the consumers and the company. Consumers' brand associations are a key element in brand management. Managers are interested in both the intensity and the strength of brand associations. This paper studies whether different types of brand associations have an impact on the purchasing decisions of consumers. This study was carried out at six of the biggest shopping malls in Ankara, Turkey with the participation of 601 consumers between the ages of 15-35.
\end{abstract}

\section{INTRODUCTION}

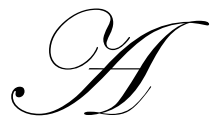

brand association is anything linked in memory to a brand (Aaker, 1991:109-110). This link becomes stronger when it is based on a consumer's frequent experiences with a specific brand. Brand associations provide great value since they represent bases for consumers' purchasing decisions as well as their level of brand loyalty. Brand associations enable companies to differentiate their brands in the market and this can prove to be a key competitive advantage. They give consumers a reason to purchase products by affecting their feelings and attitudes. In addition, brand associations provide the basis for companies in their extension efforts. Many brand associations involve product attributes or customer benefits that provide a specific reason to buy and use the brand (Aaker, 1991:112). Some associations influence consumers' purchase decisions by providing credibility and confidence in the brand. Managers are interested in both the intensity and the strength of brand associations. Their primary focus is on those associations that may affect consumers' purchasing decisions directly or indirectly.

The concept of brand associations was first discussed by Anderson (1983:75) within his "Architecture of Cognition" theory. This was a complex, comprehensive model of memory. In this model, nodes represent concepts stored in long-term memory. These nodes are interconnected by links of varying strentgh, depending on the proximity of the concepts to which they refer. A brand association is a node linked to a particular brand.

According to Keller (1993:3), these brand associations constitute the consumers' image of this brand: "brand image is defined as perceptions about a brand as reflected by the brand associations held in consumer memory". Keller classifes brand associations into three major categories: attributes, benefits, and attitudes. Attributes are those descriptive features that charactarize a brand, such as what a consumer thinks the brand is or has. Benefits are the personal value consumers attach to the brand attributes, that is, what consumers think the brand can do for them. Brand attitudes are consumers' overall evaluations of a brand.

Keller suggests classfying the various types of brand associations in 9 dimensions, while Aaker (1991) puts forward 11 dimensions. Korchia (1999) established 15 categories of associations: the company, other organizations, brand personality, celebrities and events, typical users, typical usage situations, product category, price, communication, distribution, product-related attributes, functional benefits, experiential benefits, symbolic benefits and attitude. 


\section{PURPOSE OF THE STUDY}

In this research, we test to see whether brand associations have an effect on the purchasing decisions of consumers. To be able to determine such an effect, various types of brand associations in 4 selected industries have been studied. Consumers have been analyzed based on different criteria and the type of brand association with the highest impact on consumer decision process has been evaluated.

\section{RESEARCH DESIGN AND METHODOLOGY}

This is a field study conducted with 601 consumers between the ages of 15-35 who live in Ankara, the capital city of Turkey.

\section{Determining The Sample Size}

Consumers between the ages of 15-35 have been selected for this research based on the perception that young people, compared with other age groups, place greater emphasis on brands. The study was carried out at six shopping malls in Ankara with the participation of 601 subjects. Various types of brand associations in 4 industries have been studied. These industries include automobile, non-alcoholic beverages, mobile phone and sports shoes industries.

\section{Method}

Survey method has been used to gather data. Surveys were prepared after a thorough literature review and analysis. Surveys consisted of 2 parts and a total of 14 questions. In the first part, subjects were asked about demographics and personal factors. In the second part, questions were asked regarding the subject's reactions about brand associations. Prior to conducting the field study, the validity of the survey questions was assessed through a pilot study including 40 subjects.

All of the surveys have been completed, returned and included in the study, thus the response rate was $100 \%$.

Following the return of completed surveys, their data was coded and entered into the computer. The coded data was sorted and analyzed by SPSS program. Chi-square technique was used for this analysis.

The following hypotheses were developed to be tested for this study:

H1: Brand associations have an effect on the purchasing decisions of consumers.

H 1a: There is a relationship between brand associations' effect on purchasing decision and the level of income.

H 1b: There is a relationship between brand associations' effect on purchasing decision and gender.

H 1c: There is a relationship between brand associations' effect on purchasing decision and the level of education.

H 1d: There is a relationship between brand associations' effect on purchasing decision and the city of residence.

H 2: There is a relationship between brand associations' effect on purchasing decision and the most effective (influential) factors on brand associations.

\section{FINDINGS OF THE RESEARCH}

Within the context of this study, the findings are presented below with the aid of data gathered from the result of the analysis.

\section{Allocation Of Subjects According To The Demographic Factors}

The majority of the subjects that participated in the research study are in the 21-25 age group, \%17,7 of the subjects are in 15-20 age group, \%38,9 of them are within 21-25 age group, \%21,8 of them are in 26-30 age group and the remaining $\% 21,6$ of the subjects are within 31-35 age group. Analysis reveals that $\% 55,7$ of the subjects are male and $\% 44,3$ of the subjects are female consumers. More than half of the subjects $(\% 53,7)$ who participated in the study 
have a university degree $\% 15,1$ have a graduate degree, $\% 31,1$ have a high school degree and the remaining $\% 2,7$ of the subjects have primary school degree.

Within the context of the research, the monthly average income of households has been divided into six categories and subjects were asked to choose the category that fits them. Based on this allocation, $\% 7.7$ of the subjects have a monthly income of 400-999YTL; \%15.8 of the subjects have a monthly income of $1000-1499$ YTL, \%14.5 of the subjects have a monthly income of 1500 - 1999 YTL, \%13.6 of the subjects have a monthly income of 2000 2499 YTL, \%15 of the subjects have a monthly income of $2500-2999$ YTL. The majority of the subjects $(\% 33,4)$ stated that they have an average monthly income of $3000 \mathrm{YTL}$ and over.

\section{Brands Associated With Countries (According To Industries)}

Subjects were given automobile, sport shoes, non-alcoholic beverages and mobile phone industries and from these industries, they were asked to associate brands with specified countries. The purpose of this question was to determine the effect of this particular type of (country) brand association on subjects' brand associations. In the automobile industry, \%34.8 of the subjects stated Honda cars reminds them of Japan, \%32.9 of the subjects expressed that they associate France with Renault, \%30.1 said that Tofas reminds them of Turkey, \%30.8 of the subjects associated Germany with Mercedes, \%32.1 of the subjects specified that Ferrari reminds them of Italy, \%13.5 of the subjects associated United States with Chevrolet \%29.5 of the subjects stated that Seat cars remind them of Spain. This allocation is presented in Table 2.

In the mobile phone industry, $\% 34.7$ of the subjects associated Japan with Sony Ericsson brand, $\% 10.6$ of the subjects associated France with Alcatel brand, \%9.8 of the subjects indicated that Aselsan brand reminds them of Turkey, and \%14.8 of the subjects stated that they associate Germany with Siemens. In addition, $\% 37.4$ of the subjects associated United States with Motorola brand and \%40,6 of them expressed that Nokia brand reminds them of Finland. The Sony-Ericsson joint venture in the mobile phone industry had a negative band association effect for the Swedish brand Ericsson. With the new brand Sony-Ericsson, consumers associate the product with Japan, not with Sweden. Mobile phone brands in France, Turkey, Italy and Spain had a very low (nominal) amount of brand association. Many consumers in the study had a hard time associating these countries with the relevant brands. These results indicate the need for increased promotional efforts to build brand awareness among consumers for these particular products.

In the non-alcoholic beverages industry, two brands were very dominant in terms of their association. \%39.6 of the subjects associated Cola Turka with Turkey and \%60.9 of the subjects associated Coca-Cola with the United States (Table 2). Cola Turka was positioned in the Turkish market as the main rival of Coca-Cola and it was heavily promoted to build brand awareness and loyalty. The fact that it was a Turkish product and it was packaged in a bottle bearing the national colors of red and white made the product a huge success in a relatively short period of time. One of the surprising results in this industry turned out to be the fact that none of the subjects mentioned an association for Pepsi, another strong American brand.

In the sports shoes industry, an overwhelming majority (\%71) of the subjects associated Nike brand with the United States. \%26.3 of the subjects stated that Adidas reminds them of Germany and \%18.6 said that they associate Italy with Lotto brand marka (Table 2). Nike has a powerful brand image and popular ads with famous athletes such as Michael Jordan, Tiger Woods. The result of such promotional efforts has cultivated a strong brand association for the brand and its country.

\section{The Most Effective Factors On Brand Associations (According To Industries)}

In the research study, the subjects were asked to rate the following 5 factors in order of importance regarding the impact these factors have on brand associations. The 5 factors consisted of the logo of the brand, the color of the brand, the country that the brand belongs to, the cingle of the brand, and the slogan of the brand. 
In the automobile industry, $\% 48,1$ of the subjects identified the logo of the brand as the most effective factor. The country the brand belongs to was stated as the second most important factor on brand associations. In this industry, the least effective factors on brand association were identified as the color of the brand and the slogan of the brand.

For the mobile phone industry, $\% 32,4$ of the subjects expressed the three most effective factors as the logo of the brand, the cingle $(\% 22,1)$ and the slogan of the brand $(\% 16,6)$. In the non-alcoholic beverages industry, $\% 25,8$ of the subjects identified the logo of the brand as the most effective factor. \%21,6 of the subjects indicated the country that the brand belongs to as the second most influential factor on brand associations. Within the sport shoes industry, $\% 36,9$ of the subjects agreed that the logo of the brand is the most effective factor while the slogan of the brand was regarded as the second most effective factor on brand associations (Table 3).

Analysis reveals the brand logo as the most prominent, effective factor for consumers in terms of their brand associations. The visual nature of the logos enables consumers to create a mental image for the brand. The results indicate that due to their verbal nature, the cingles and slogans are not as effective as the brand logos.

Table 3: Most Effective Factors On Brand Associations (According To Industries)

\begin{tabular}{|c|c|c|c|c|c|c|c|c|c|c|}
\hline Industries & & & & & & & & & & \\
\hline Automobile Industry & $1 *$ & $\%$ & 2 & $\%$ & 3 & $\%$ & 4 & $\%$ & 5 & $\%$ \\
\hline The Logo of the Brand & 95 & 15,8 & 70 & 11,6 & 67 & 11,1 & 62 & 10,3 & 289 & 48,1 \\
\hline The Color of the Brand & 164 & 27,3 & 91 & 15,1 & 106 & 17,6 & 155 & 25,8 & 67 & 11,1 \\
\hline The Country of the Brand & 83 & 13,8 & 73 & 12,1 & 173 & 28,8 & 151 & 25,1 & 103 & 17,1 \\
\hline The Cingle of the Brand & 93 & 15,5 & 254 & 42,3 & 118 & 19,6 & 63 & 10,5 & 55 & 9,2 \\
\hline The Slogan of the Brand & 143 & 23,8 & 102 & 17,0 & 124 & 20,6 & 153 & 25,5 & 61 & 10,1 \\
\hline Mobile Phone Industry & 1 & $\%$ & 2 & $\%$ & 3 & $\%$ & 4 & $\%$ & 5 & $\%$ \\
\hline The Logo of the Brand & 104 & 17,3 & 70 & 11,6 & 126 & 21,0 & 88 & 14,6 & 195 & 32,4 \\
\hline The Color of the Brand & 123 & 20,5 & 157 & 26,1 & 110 & 18,3 & 138 & 23,0 & 55 & 9,2 \\
\hline The Country of the Brand & 143 & 23,8 & 114 & 19,0 & 136 & 22,6 & 95 & 15,8 & 95 & 15,8 \\
\hline The Cingle of the Brand & 63 & 10,5 & 148 & 24,6 & 127 & 21,1 & 112 & 18,6 & 133 & 22,1 \\
\hline The Slogan of the Brand & 152 & 25,3 & 91 & 15,1 & 89 & 14,8 & 151 & 25,1 & 100 & 16,6 \\
\hline Non-Alc. Beverages Industry & 1 & $\%$ & 2 & $\%$ & 3 & $\%$ & 4 & $\%$ & 5 & $\%$ \\
\hline The Logo of the Brand & 135 & 22,5 & 71 & 11,8 & 103 & 17,1 & 119 & 19,8 & 155 & 25,8 \\
\hline The Color of the Brand & 118 & 19,6 & 148 & 24,6 & 110 & 18,3 & 140 & 23,3 & 67 & 11,1 \\
\hline The Country of the Brand & 112 & 18,6 & 99 & 16,5 & 143 & 23,8 & 99 & 16,5 & 130 & 21,6 \\
\hline The Cingle of the Brand & 70 & 11,6 & 160 & 26,6 & 128 & 21,3 & 116 & 19,3 & 109 & 18,1 \\
\hline The Slogan of the Brand & 141 & 23,5 & 102 & 17 & 95 & 15,8 & 122 & 20,3 & 123 & 20,5 \\
\hline Sports Shoes Industry & 1 & $\%$ & 2 & $\%$ & 3 & $\%$ & 4 & $\%$ & 5 & $\%$ \\
\hline The Logo of the Brand & 68 & 11,3 & 60 & 10,0 & 133 & 22,1 & 97 & 16,1 & 222 & 36,9 \\
\hline The Color of the Brand & 105 & 17,5 & 117 & 19,5 & 112 & 18,6 & 169 & 28,1 & 77 & 12,8 \\
\hline The Country of the Brand & 125 & 20,8 & 89 & 14,8 & 121 & 20,1 & 157 & 26,1 & 88 & 14,6 \\
\hline The Cingle of the Brand & 118 & 19,6 & 185 & 30,8 & 121 & 20,1 & 73 & 12,1 & 83 & 13,8 \\
\hline The Slogan of the Brand & 168 & 28,0 & 126 & 21,0 & 104 & 17,3 & 88 & 14,6 & 94 & 15,6 \\
\hline
\end{tabular}

\section{The Impact Of Slogans On Brand Associations}

Subjects in the research were given a list of slogans and asked to match these slogans with the appropriate brands. Based on the associations from their memories, \%94 of the subjects was able to match Motorola with its slogan, \%92,5 matched Nokia, \%85,9 of them matched Coca-Cola, \%85,5 managed to match Sprite, \%81,5 succeed in matching Redbull with its slogan. In addition, \%81 of the subjects matched Nike, \%71,7 matched Slazenger, \%67,6 matched Volkswagen, \%66,1 matched Kinetix, \%65,1 managed to match Pepsi, \%61,9 matched Siemens and lastly, $\% 58,9$ of the subjects matched Adidas with its appropriate slogan. This allocation is presented in Table 4 below. 
In the automobile industry, most of the slogans were mismatched by the subjects, thus leading to the conclusion that using slogans to create brand associations proves to be unsuccessful in this sector. Companies operating in this industry should re-evaluate their slogans and make the necessary adjustments in order to create slogans that will leave an imprint on the minds of consumers.

Contrary to the auto industry, Motorola and Nokia, from the mobile phone industry, seem to be very successful in creating brand associations with their slogans. In the non-alcoholic beverages industry, most of the subjects were able to match the slogans with the correct brands. The only brand that had a low matching rate, compared to other brands, was Pepsi. In the sports shoes industry, Nike and Slazenger were the top brands with the highest matching rate. Adidas, however, was not regarded as effective in terms of its slogan. Many subjects were unable to match Adidas with its slogan.

Table 4: The Impact Of Slogans On Brand Associations

\begin{tabular}{|c|c|c|c|c|c|c|c|c|}
\hline \multirow{2}{*}{ Industry } & \multirow{2}{*}{ Slogans } & \multicolumn{6}{|c|}{ Matching } & \multirow{2}{*}{$\begin{array}{c}\text { I don't } \\
\text { Know } \\
(\%)\end{array}$} \\
\hline & & 1 & $\%$ & 2 & $\%$ & 3 & $\%$ & \\
\hline \multirow{4}{*}{ Automobiles } & "Drivers Wanted" & VW & 67,6 & A.Romeo & 4,7 & Audi & 1,0 & 26,7 \\
\hline & $\begin{array}{l}\text { "Advancement through } \\
\text { Technology" }\end{array}$ & Audi & 22,0 & Toyota & 9,3 & A.Romeo & 5,2 & 63,5 \\
\hline & "Beauty is notEnough" & A.Romeo & 20,1 & Toyota & 10,1 & Audi & 5,7 & 64,1 \\
\hline & $\begin{array}{l}\text { "Advancement through } \\
\text { Technology" }\end{array}$ & Audi & 15,5 & Toyota & 15,3 & A.Romeo & 6,0 & 63,2 \\
\hline \multirow{4}{*}{$\begin{array}{l}\text { Mobile } \\
\text { Phones }\end{array}$} & "Hello Moto" & Motorola & 94,0 & S.Ericsson & 0,7 & Pepsi & 0,3 & 5,0 \\
\hline & "Connecting People" & Nokia & 92,5 & Siemens & 0,3 & Pepsi & 0,3 & 6,9 \\
\hline & "Be inspired" & Siemens & 61,9 & S.Ericsson & 6,3 & Audi & 1,2 & 30,6 \\
\hline & $\begin{array}{l}\text { "Tomorrow and } \\
\text { Beyond" }\end{array}$ & S.Ericsson & 23,8 & A.Romeo & 5,7 & Pepsi & 2,0 & 68,5 \\
\hline \multirow{4}{*}{$\begin{array}{c}\text { Non- } \\
\text { alcoholic } \\
\text { Beverages }\end{array}$} & "The Real Thing" & Coca-Cola & 85,9 & Pepsi & 0,5 & Cola Turka & 0,2 & 13,4 \\
\hline & $\begin{array}{l}\text { "Image is nothing, thirst } \\
\text { is everything" }\end{array}$ & Sprite & 85,5 & Pepsi & 0,8 & VW & 0,7 & 13,0 \\
\hline & "It Gives You Wings" & Redbull & 81,5 & Kinetix & 1,8 & Slazenger & 1,3 & 15,4 \\
\hline & "Ask For More" & Pepsi & 65,1 & Coca-Cola & 1,0 & Slazenger & 0,8 & 33,1 \\
\hline \multirow{4}{*}{ Sports Shoes } & "Just Do It" & Nike & 81,0 & Adidas & 3,7 & Kinetix & 1,2 & 14,1 \\
\hline & "Sheer Instinct" & Slazenger & 71,7 & Kinetix & 3,8 & Adidas & 1,5 & 23,0 \\
\hline & "Run or You will Fall" & Kinetix & 66,1 & Adidas & 4,3 & Slazenger & 1,8 & 27,8 \\
\hline & "Impossible Is Nothing" & Adidas & 58,9 & S.Ericsson & 2,5 & Siemens & 1,8 & 36,8 \\
\hline
\end{tabular}

\section{Subjects' Perceptions Of Brand Logos}

Subjects were presented $14 \operatorname{logos}$ from all 4 of the industries and asked to specify the appropriate brand. As Table 5 reveals, a majority of the subjects were able to match the logo with the correct brand. $\% 97,8$ of the subjects knew the logo of Motorola. \%95 knew the logo of Volkswagen whereas \%94,5 correctly specified the logos of Pepsi and Adidas. \%94 of the subjects in the study knew the logo of Toyota, with $\% 93,7$ of them pointing out the logo for Nokia. In addition, subjects were able to match the logos for Audi $(\% 90,7)$, Sony-Ericsson (\%85), Alfa Romeo $(\% 82,4)$, Puma $(\% 78,4)$, and Ferrari $(\% 77,2)$.

The results indicate that, based on the industries, mobile phone industry had the highest percentage of correct matching between the logo and the brand. An overwhelming majority $(\% 97,8)$ of the consumers who participated in the study did know Motorola's logo. It can be concluded that Motorola has very high brand awareness. The automobile industry came up a close second in the analysis for logos. \%95 of the subjects knew Volkswagen's logo correctly. Sports shoes and non-alcoholic beverages in industries took places as the third and fourth place respectively. 
It has been observed hat some of the subjects confused Slazenger and Puma's logos with that of Jaguar cars. It may be a good idea for these particular companies to make some changes in their logos to differentiate themselves. Such differentiation will be very useful for brand association and brand awareness of their consumers.

Table 5: The Ratio Of Subjects' Logo Perception (\%)

\begin{tabular}{|c|c|c|}
\hline Logos & Brand Name & $\begin{array}{c}\text { Ratio of Subjects That } \\
\text { Know the Logo }\end{array}$ \\
\hline & Motorola & 97,8 \\
\hline & Volkswagen & 95,0 \\
\hline & Pepsi & 94,5 \\
\hline & Adidas & 94,5 \\
\hline & Toyota & 94,0 \\
\hline & Nokia & 93,7 \\
\hline & Audi & 90,7 \\
\hline & Sony Ericsson & 85 \\
\hline & Alfa Romeo & 82,4 \\
\hline
\end{tabular}

\section{ANALYSIS OF HYPOTHESES}

\section{Analyzing The Relationship Between Brand Associations' Effect On Purchasing Decision And The Level Of Income}

The relationship between brand associations' effect on purchasing decision and the level of income was examined by chi-square analysis technique. The probability value $(\alpha=0,05)$ is greater than the level of significance, thus, we accept $\mathbf{H}_{1 \mathbf{a}}$ hypothesis. The result indicates that there is indeed a relationship between brand associations' effect on purchasing decision and the level of income. 


\section{Analyzing The Relationship Between Brand Associations' Effect On Purchasing Decision And Gender}

After the analysis for these two variables, the probability value $(\alpha=0,05)$ is less than the level of significance. In this situation, we reject $\mathbf{H}_{\mathbf{1 b}}$ hypothesis. There is no relationship between brand associations' effect on purchasing decision and gender.

\section{Analyzing The Relationship Between Brand Associations' Effect On Purchasing Decision And The Level Of Education}

After the analysis for these two variables is conducted, it is observed that there is a relationship between brand associations' effect on purchasing decision and the level of education. The probability value $(\alpha=0,05)$ is greater than the level of significance, thus we accept $\mathbf{H}_{\mathbf{1}}$ hypothesis.

\section{Analyzing The Relationship Between Brand Associations' Effect On Purchasing Decision And The City Of Residence}

After the analysis for these two variables, the probability value $(\alpha=0,05)$ is greater than the level of significance. Therefore, we accept $\mathbf{H}_{\mathbf{1 d}}$ hypothesis and conclude that there is a relationship between brand associations' effect on purchasing decision and the city of residence.

Analyzing The Relationship Between Brand Associations' Effect On Purchasing Decision And The Most Effective Factors On Brand Associations

For the logo of the brand, chi-square analysis indicate that the probability value $(\alpha=0,05)$ is greater than the level of significance. Therefore, we state that, in all 4 of the selected industries, there is a relationship between brand association's effect on purchasing decision and the brand logo.

For the color of the brand, the probability value $(\alpha=0,05)$ is greater than the level of significance in mobile phone, non-alcoholic beverages and sports shoes industries. Thus, we conclude there is a relationship between brand associations' effect on purchasing decision and the brand's color in these three particular industries. However, no such relationship is observed within the automobile industry.

For the cingle of the brand, chi-square analysis indicate that the probability value $(\alpha=0,05)$ is greater than the level of significance. Therefore, we state that, in all 4 of the selected industries, there is a relationship between brand association's effect on purchasing decision and the brand cingle.

For the slogan of the brand, chi-square analysis indicate that the probability value $(\alpha=0,05)$ is greater than the level of significance. Therefore, we state that, in all 4 of the selected industries, there is a relationship between brand association's effect on purchasing decision and the brand slogan.

\section{Analyzing The Relationship Between The Effect Of Brand Associations On Consumers' Purchasing Decisions}

The main hypothesis $\left(\mathrm{H}_{1)}\right.$ of the research states that brand associations have an effect on consumers' purchasing decisions. After the analysis for this particular hypothesis, it is observed that the $Z_{H}$ value is less than the value of 1,96 . Therefore, we accept the $\mathrm{H}_{1}$ hypothesis. Out of the 601 consumers who participated the research, \%68,5 expressed that brand associations do have an effect on their purchasing decisions. On the other hand, \%14,3 of the participants disagreed, claiming that brand associations do not affect their purchasing decisions. $\% 17,2$ of the subjetcs were undecided about this issue.

It is important to point out that the result of this research is limited to four industries and may not be generalizable for the other industries. Results of a research conducted on various other industries may paint a different picture. 


\section{CONCLUSION}

The complex nature of competition and increasingly demanding consumers in the global markets force companies to create competitive marketing strategies. As companies are developing these marketing strategies, they focus heavily on the brand concept since brands add a great value to their products and services. During the development of brands, the main goal is creating a unique value specific to that brand. This unique value is more of an abstract nature, and includes the image, associations, perception, status, and quality concepts. The brand gets stronger with the value attached to it and establishes not only a competitive place in the market but also a permanent position in the minds of consumers.

This study aims to determine the impact of brand associations on consumers. Different types of brand associations in four selected industries (automobile, mobile phone, sports shoes and non-alcoholic beverages industries) are evaluated by consumers who participated in the research. The major goal is to discover the effect of brand associations on the purchasing decisions of consumers. The consumers are asked to focus on various criteria regarding the brands in the selected industries and their attitudes towards the brands are studied.

The analysis reveals that in all four of the industries the effect of various types of brand associations can be quite different. This is true for brands from different industries as well as brands that compete within the same industry. The good news is that results indicate consumers have mostly developed successful brand associations, that a majority of the studied brands have a significant place in their memory. When consumers positively associate with a particular brand, they accept, favor and desire that brand. This eventually affects their repurchase decisions. Therefore, it is crucial for companies to put a great effort in creating strong, unique, one-of-a-kind associations with their brands. By doing so, they will be able to leave an imprint, a distinct position in the minds of their consumers.

\section{REFERENCES}

1. $\quad$ Aaker, David and S.G. Shansby, Positioning Your Product. Business Horizons, Volume: 25, 1982.

2. Aaker, David and G. Day, Marketing Research (4th Edition), Ch: 9, 17 - 19. John Wiley, New York, 1990.

3. $\quad$ Aaker, David, Managing Brand Equity. The Free Press, New York, 1991.

4. Aaker, David, R. Batra, and J. Myers, Advertising Management (4th Edition). Prentice Hall, Engelwood Cliffs, New Jersey, 1992.

5. Aaker, David, The Value of Brand Equity. Journal of Business Strategy, Volume: 13, Issue: 4, 1992.

6. Aaker, David, Measuring Brand Equity Across Products \& Markets. California Management Review, Volume: 38, No: 3, 1992.

7. $\quad$ Aaker, David, Building Strong Brands. The Free Press, New York, 1996.

8. Alba, Joseph W. and Wesley, J. Hutchinson, Dimension of Consumer Expertise. Journal of Consumer Research, Volume: 13, 1987.

9. $\quad$ Alsop, Ronald, Brand Loyalty is Rarely Blind Loyalty, The Wall Street Journal, 1989.

10. Alexrod, Joel N. and Hans Wybenga, Perceptions That Motivate Purchase, Journal of Advertising Research; June, 1985.

11. Ambler, Tim and Chris Styles, Brand Development Versus New Product Development: Toward a Process Model Of Extensions Decisions, Journal of Product \& Brand Management, Volume: 6, No: 4, 1996.

12. Anderson, R. John, The Architecture of Cognition, MA: Harvard University Press, Cambridge, 1983.

13. Arnold, David, The Handbook of Brand Management $\left(1^{\text {st }}\right.$ Edition), Addision-Wesley Publishing Company, 1993.

14. Keller, Kevin Lane and David Aaker, The Effects of Sequential Introduction of Brand Extensions, Journal of Marketing Research. Volume: 29, 1992.

15. Keller, Kevin Lane, Conceptualizing, Measuring \& Managing Customer-Based Brand Equity, Journal of Marketing. Volume: 57, Issue: 1, 1993.

16. Keller, Kevin Lane, The Brand Report Card, Harvard Business Review. Volume: 78, 2000.

17. Korchia, Michael, The Effects of Brand Associations on Three Constructs, Proceedings From the 33rd EMAC Conference, 2004.

18. Murphy, M. John, Branding: A Key Marketing Tool, McMillan, New York, 1987. 